\title{
A case of trichotillomania with pica, encopresis and attention deficit hyperactivity disorder in a 6 year old girl
}

\author{
*Prathamesh Kulkarni ${ }^{1}$, Reetika Dikshit ${ }^{2}$, Nilesh Shah ${ }^{3}$, Rimple Limbachiya ${ }^{4}$, Avinash Desousa ${ }^{5}$
}

Sri Lanka Journal of Child Health, 2017; 46(2): 88-90

DOI: http://dx.doi.org/10.4038/sljch.v46i1.8026

(Key words: Trichotillomania, pica, encopresis, attention deficit hyperactivity disorder, comorbidity)

\begin{abstract}
Introduction
Trichotillomania (TTM) is characterized by recurrent pulling of one's own hair resulting in hair loss ${ }^{1}$. It is currently classified as an obsessive-compulsive related disorder in DSM $5^{1}$. Most common sites are scalp, eyebrows and eyelids ${ }^{2}$. Prevalence in Indian children is $1.24 \%$ as reported by Malhotra et $\mathrm{al}^{2}$. Onset of trichotillomania is usually around puberty; however, there are reports documenting onset as early as 18 months $^{3}$. Although early childhood TTM has often been described to be a benign habit, in clinical practice it can be worrying to the child and the parents, and also can cause disturbance in family and academic functioning ${ }^{3}$. There are many conditions reported to be co-morbid with trichotillomania in children including mental retardation, thumb sucking, enuresis, depression, eating disorder and encopresis ${ }^{2}$.
\end{abstract}

\section{Case report}

A 6 year old right handed girl, a resident of Mumbai, Hindu by religion, Hindi speaking, studying in junior kindergarten English medium school was referred from the dermatology department for repetitive pulling of her scalp hair. She was the first of 3 siblings, born of a non-consanguineous marriage by natural conception. It was a full term normal vaginal delivery in hospital. She cried well at birth. Her birth weight was $2.5 \mathrm{~kg}$. There were no antepartum, intrapartum or postpartum complications. She was

$\overline{{ }^{1} \text { Ex- Specialty Medical Officer, }{ }^{2} \text { Resident Doctor, }}$ ${ }^{3}$ Professor and Head, ${ }^{4}$ Ex Senior Resident, ${ }^{5}$ Research Officer, Department of Psychiatry, Lokmanya Tilak Municipal General Hospital, Sion, Mumbai, India

*Correspondence:drprathameshkulkarni@gmail.com

(Received on 6 October 2015: Accepted after revision on 20 November 2015)

The authors declare that there are no conflicts of interest

Personal funding was used for the project.

Open Access Article published under the Creative

Commons Attribution CC-BY (CC) (i) immunized well up to date. Her developmental history was normal. For the past 4 months she started pulling her scalp hair many times in a day. This pulling of hair resulted in patchy loss of hair. Parents tried to stop her behaviour by scolding and also shaving off her hair.

However, it recurred back on re-growth of hair. This hair pulling had resulted in cosmetic problems and also social problems as she would do this in social gatherings and at school which affected her studies. On asking the child about this behaviour, she claimed that she would get an irresistible urge to pull the hair and after pulling the hair she would feel comfortable. Dermatologist had ruled out any underlying dermatological pathology for hair loss.

On detailed enquiry, although patient and mother claimed she never ate hair, mother revealed that since past 4 months patient had started eating mud and dirt particles fallen on ground. She puts all the fingers of both hands in mouth. She continued to do so despite being punished for same. Mother also complained that patient used to pass faeces in her clothes at least 3-4 times a week mostly during daytime. On a few occasions patient would ask to take her to the toilet. However, mother denied her passing faeces in clothes at night time. Mother also denied passing of urine in clothes. Mother also stated she was unable to sit at one place for a long time. She was very restless and constantly running about the house and climbing the windows. She was unable to play a game for more than 5 minutes and would need a new game to engage her. She would often interrupt her elders in their conversations. Mother also stated that teachers in school often complain that she is very restless and fidgety in the classroom, often disturbing other students. She knew academics orally but her notebooks were incomplete. She would often forget her stationery at school. She would often indulge in fights with cousins of her age and hit her younger sibling without any reason. She does not follow given instructions. She is not able to maintain self-care. There was no history suggestive of autism spectrum disorder, depression, schizophrenia or intellectual 
disability. Mother denied any significant past medical, surgical or family history.

On interview, she was seen to have a receding hairline at temporal region with short hair. She was very fidgety and restless. She was not sitting quietly at one place and was continuously pacing around the room. She was not attentive towards questions being asked from her. Occasionally she would also pull her scalp hair. Her blood investigations, including complete haemogram, liver and renal functions tests, were within normal limits. Gastroenterology referral to rule out organic causes for encopresis, did not reveal any organic cause. Ultrasonography (USG) of abdomen was normal. The patient was diagnosed to have trichotillomania with pica, encopresis and attention deficit hyperactivity disorder.

Mother was given instructions about "star charting" as behaviour therapy, and with this patient stopped passing faeces in clothes. She was also started on fluoxetine $10 \mathrm{mg}$ in the morning along with methylphenidate $5 \mathrm{mg}$. She developed side effects in the form of loss of appetite. So methylphenidate was stopped and her appetite improved. Fluoxetine was gradually increased to $20 \mathrm{mg}$ following which trichotillomania and pica improved $100 \%$. For her hyperactivity risperidone $0.25 \mathrm{mg}$ was started to which patient showed improvement so it was increased to $0.5 \mathrm{mg}$. At present patient is maintained on these medicines.

\section{Discussion}

Trichotillomania is a disturbing illness for patients and relatives, more so, when it is there along with other co-morbidities like attention deficit hyperactivity disorder (ADHD), pica or encopresis. A study by White et al showed that there is disordered reward processing at the level of nucleus accumbens, involving decreased modulatory input from the dorsal anterior cingulate cortex and the basolateral amygdale. This may play a role in the pathophysiology of $\mathrm{TTM}^{4}$. Also, dysfunction of the nucleus accumbens core may be a key element in the neuropathology of impulsivity ${ }^{5}$. A study done by Russel, suggests a defect in neuronal circuits that are required for reward-guided associative learning and memory formation in patients with ADHD, which usually includes nucleus accumbens and its connections $^{6,7}$. In a study done by Yin et al, it was seen that reward-guided learning is also a function of cortico-basal ganglia networks ${ }^{7}$. Abnormalities of the basal ganglia (BG), which function in voluntary motor control are also implicated in the pathophysiology of $\mathrm{TTM}^{8}$. These findings can explain ADHD and TTM comorbidity. Pica is also considered to be similar to obsessive-compulsive disorder (OCD) in respect of phenomenology and psychobiology like TTM ${ }^{9}$. TTM and encopresis have components of aggressiveness ${ }^{10}$. Encopresis is also commonly co-morbid with ADHD. Furthermore, treatment for ADHD can improve encopresis ${ }^{11}$. Thus, the co-morbidity of TTM, ADHD, pica and encopresis can be explained biologically. These comorbidities do not only add up to impairments but also they cause difficulties in management. It is seen in earlier research that patients having ADHD with more than 3 co-morbidities show reduced response rate to management ${ }^{12}$.

In our patient there was trichotillomania, pica and encopresis along with ADHD. According to parents, TTM and ADHD were the most distressing of these four diagnoses. Methyphenidate $(5 \mathrm{mg})$ was started as it is the drug of choice for $\mathrm{ADHD}^{13}$. Although behaviour therapy is recommended for childhood $\mathrm{TTM}^{3}$, our patient was unable to follow the therapy and hence fluoxetine was started. Behaviour therapy has been shown to be effective in encopresis; thus mother was taught about star charting which is based on positive reinforcement. However, methyphenidate is known to cause loss of appetite and weight loss ${ }^{13}$. This patient developed these side effects so we stopped methylphenidate. Her appetite and weight improved after stopping this medicine but her hyperactivity worsened. Risperidone has been shown effective in controlling hyperactivity in $\mathrm{ADHD}^{14}$. Thus, for her hyperactivity low dose risperidone $(0.25 \mathrm{mg})$ was started and with that her hyperactivity was also decreased.

\section{References}

1. American Psychiatric Association. Diagnostic and statistical manual of mental disorders. 5th ed. 2013.

Available from:

http://dsm.psychiatryonline.org/doi/book/10. 1176/appi.books.9780890425596

2. Malhotra S, Grover S, Baweja R, Bhateja G. Trichotillomania in children. Indian Pediatrics 2008; 45(5): 403-5. PMid: 18515931

3. Park JM, Rahman O, Murphy TK, Storch EA. Early childhood trichotillomania: Initial considerations on phenomenology, treatment, and future directions. Infant Mental Health Journal 2012; 33(2):163-72. http://dx.doi.org/10.1002/imhj.21317 
4. White MP, Shirer WR, Molfino MJ, Tenison C, Damoiseaux JS, Greicius MD. Disordered reward processing and functional connectivity in trichotillomania: a pilot study. Journal of Psychiatric Research 2013; 47(9):1264-72.

http://dx.doi.org/10.1016/j.jpsychires.2013.0 5.014

PMid: 23777938

5. Cardinal RN. Impulsive choice induced in rats by lesions of the Nucleus Accumbens Core. Science 2001; 292(5526):2499-501. http://dx.doi.org/10.1126/science.1060818 PMid: 11375482

6. Russell VA. Dopamine hypofunction possibly results from a defect in glutamatestimulated release of dopamine in the nucleus accumbens shell of a rat model for attention deficit hyperactivity disorder - the spontaneously hypertensive rat. Neuroscience and Biobehavioral Reviews 2003; 27(7):671-82.

http://dx.doi.org/10.1016/j.neubiorev.2003.0 8.010

PMid: 14624811

7. Yin HH, Ostlund SB, Balleine BW. Rewardguided learning beyond dopamine in the nucleus accumbens: the integrative functions of cortico-basal ganglia networks. European Journal of Neuroscience 2008; 28(8): 1437 48.

http://dx.doi.org/10.1111/j.14609568.2008.0 6422.x

PMid: 18793321 PMCid: PMC2756656

8. Roberts K, Stanley EM, Franklin ME, Simons RF. Decreased response monitoring in individuals with symptoms of trichotillomania. Psychophysiology 2014; 51(7):706-13. http://dx.doi.org/10.1111/psyp.12205

PMid: 24646325

9. Stein DJ, Bouwer C, Van Heerden B. Pica and the obsessive-compulsive spectrum disorders [Internet]. 1996 [cited 2015 Oct 6]. Available from:

http://scholar.sun.ac.za/handle/10019.1/7231
10. Harbauer H. [The aggressive child (author's transl)]. Monatsschr. Kinderheilkd. [Internet]. 1978 Aug [cited 2015 Oct 6]; 126(8):472-8. Available from: http://www.ncbi.nlm.nih.gov/pubmed/35587 2

11. Niemczyk J, Equit M, Hoffmann L, von Gontard A. Incontinence in children with treated attention deficit hyperactivity disorder. Journal of Pediatric Urology 2015; 11(3):141.e1-6. http://dx.doi.org/10.1016/j.jpurol.2015.02.00 9

PMid: 25863677

12. Ghuman JK, Riddle MA, Vitiello B, Greenhill LL, Chuang SZ, Wigal SB, et al. Comorbidity moderates response to methylphenidate in the Preschoolers with Attention-Deficit/Hyperactivity Disorder Treatment Study (PATS). Journal of Child and Adolescent Psychopharmacology 2007; 17(5):563-80.

http://dx.doi.org/10.1089/cap.2007.0071

PMid: 17979578

13. Reddy DS. Current pharmacotherapy of attention deficit hyperactivity disorder. Drugs Today (Barc). 2013; 49(10):647-65.

14. Arabgol F, Panaghi L, Nikzad V. Risperidone versus methylphenidate in treatment of preschool children with attention-deficit hyperactivity disorder. Iranian Journal of Pediatrics 2015; 25(1):e265. http://dx.doi.org/10.5812/ijp.265

PMid: 26199694 PMCid: PMC4505976 